\title{
Putri Renjani Manisan Product Standardization: The Efforts to Increase Product Sales in Pandemic
} \section{Situations}

\section{| Nurmala Berutu ${ }^{1}$ | Hodriani ${ }^{2, *}$ | Dwi Budiwiwaramulja ${ }^{3}$ |}

${ }^{1}$ Geography Department, Universitas Negeri Medan, Indonesia

${ }^{2}$ Pancasila and Civic Education, Universitas Negeri Medan, Indonesia

${ }^{3}$ Fine Art Department, Universitas Negeri Medan, Indonesia

*hodrianisitompul@gmail.com

\begin{abstract}
Recently, Indonesia experienced a major disaster caused by Covid19 which was also experienced by other countries such as China. This had a huge impact so as to shake the stability of the country. Attacking public health, especially the economy. The Covid-19 pandemic in Indonesia has occurred since March 2020 until now. This also has an impact on the income of creative businesses or home industries. This research will specifically examine the role of Putri Ranjani Manisan product standardization in the Business Group for Increasing Prosperous Family Income (Usaha Peningkatan Pendapatan Keluarga Sejahtera/ UPPKS) Kasih Ibu Kampung KB, Limau Sundai Binjai Village and product commercialization in an effort to increase income during this pandemic. The research method used to examine this research is to use qualitative method with an experimental approach to the existence of the creative industry "Putri Ranjani Manisan" in the Business Group for Increasing Prosperous Family Income (UPPKS) Kasih Ibu Kampung KB Limau Sundai Binjai Village. The research results show that the role of standardization is very helpful in increasing the quantity of product sales during this pandemic. The role of standardization also supports the quality of product quality, from taste, hygiene, packaging, and halal certificates to products. During the pandemic, consumers prioritize trust in clean and hygienic products and can be trusted through MUI halal certificate. In addition, home industrial products must also have good and clean management in the process of managing products, especially food products. Therefore, local governments must play a role in providing support for creative household businesses so that they are more able to compete in the global market and support the regional economy.

KEYWORDS

product standardization; creative home industry; Putri Ranjani Manisan.
\end{abstract}

\section{INTRODUCTION}

Recently, the whole world has been impacted by Covid-19 Pandemic. This is the biggest disaster experienced by every resident on Earth. Where all countries, both forward and developing countries, are experiencing a crisis, without exception, Indonesia is one of the countries most affected by this pandemic. Indonesia is also one of the countries with the highest Covid-19 cases of all countries in the world. According to WHO (January, 2021) stated that there have been 869,600 confirmed cases of Covid-19 with 25246 deaths.

So that Indonesia experienced a severe crisis attacking the main stability, namely the economy and education. This is because the Indonesian government must enforce massively 
no crowds and overly intense social contacts. This makes all the activities of the Indonesian population begin to be disrupted, even if it has stopped like work activities. A large number of workers, and private and government workers on temporary holidays. There is even a reduction in career opportunities and unilateral dismissal by private companies.

So many people decide to look for alternatives to make a living. They are forced to build their own businesses, such as creative businesses or home. It happened because they are fired or dismissal by company. So, for supporting economic growth during this pandemic, it is necessary to prepare a standardization of products produced by the creative industry so that people's rights can be protected. In addition, other problem arose where creative entrepreneurs or home industries have to compete with global markets that already had consumer trust in product hygiene. Where the most important thing is to build consumer confidence in the products offered. Especially it is for the food product. Because the consumers are very careful about getting food products that are hygienic, clean, and can be certified. So that many consumers choose outside products that are very well packaged and clean and also have MUI certification. Therefore, the product standardization of creative and home industry products can build consumer confidence and can also be a tool to encourage the achievement of competitive advantage through increasing industrial efficiency and productivity. This is also useful for helping the income and economy of households and the region. Even standardization can reduce the production of imported products.

On the other hand, the purpose of standardization and certification for creative or home industry products is not only but it also to protect creative industry producers themselves so that their products are not imitated by other parties. In addition, consumers and governments also need guarantees that the products, processes and systems used in the creative industry have met predetermined standardization requirements. So that it builds confidence in consumers in the future.

According to the National Standardization Agency for Indonesia (2014) product standardization is to ensure safety, safety and health for the wearer. Examples: seat belts, helmets, rubber gloves, setting limits on safety for the use of dyes or preservatives in food, determining electrical insulation requirements for household electrical appliances, designing electric irons should be such that users are free from electric shocks and so on.

Benefits of standardization according to Dr. Koi Annan, Secretary General of the United Nations for the 1997-2006 period, said that standardization made a very good contribution in various fields of life such as in the fields of health, safety, security, environment, transportation and information technology (ISO Management System, November-December 2004 Edition, page 23). According to Dr. Koi Annan, standardization has also proven to provide the following benefits:

1. Streamlining transactions in the flow of goods and services in domestic and international trade by removing technical barriers in trade through harmonization of standards.

2. Help accelerate the dissemination of management systems, technology and innovation, especially among Small and Medium Enterprises in various regions and also many countries including developing countries.

3. Improve business competitiveness with a focus on quality, safety, safety, health and environmental preservation.

4. Facilitating assessment and verification of conformity.

5. Optimization in increasing standardization

6. Also specifically provides benefits to consumers, producers, suppliers and scientists. 


\section{LITERATURE REVIEW}

Standard definition and standardization used by National Standardization Body (Badan Standarisasi Nasional/ BSN)is referred to from number 102 of 2000 are as follows:

1. Standard is a technical specification or something that is standardized including procedures and methods that are prepared based on the consensus of all parties concerned with regard to the requirements of safety, security, health, the environment, developments in science and technology, as well as experiences, current developments and the future to get the greatest benefit.

2. Standardization is the process of formulating, stipulating, implementing and revising standards, which are carried out in an orderly manner in cooperation with all interested parties.

3. The Indonesian National Standard (Standar Nasional Indonesia/ SNI) is a standard set by the National Standardization Body (Badan Standardisasi Nasional/ BSN) and applies nationally.

While the objectives of standardization in general according to Sanders, 1972 in "The aims and principles of Standardization" are as follows:

1. fitness for purpose is an ability of a process, product or service to fulfill a specified use under certain specific conditions. Every process, product or service is intended to meet the needs of the user. Standards are useful for identifying the optimum parameters for the performance of a process, product or service and methods for evaluation of compliance with related requirements. Standards may also require conditions for the use of processes, products or services to prevent process, product or service failures due to inappropriate use by users or due to non-compliance of process, product or service quality requirements.

2. Interchangeability is to conformity that a product, process or service can be used to replace and meet relevant requirements is called interchangeability. Through standard setting processes, products or services are interchangeable. Example: razors of different brands can be used in the same shaver.

3. Diversity control is one of the objectives of controlling diversity is to determine the optimum size, grade, composition, "rating", and working practices to meet certain needs. The excessive amount of variety will make it difficult for consumers to choose the product that suits their wishes and from the producer point of view it will increase production costs. Example: standard paper sizes (A series).

4. Compatibility The purpose of compatibility is the suitability of a process, product or service to be used simultaneously with specific conditions to meet relevant requirements, without causing unwanted interactions. Example: electronic data processing, information must be in the form of code for storage, transmission and retrival in the form of electronic pulses. In order for the code to be recognized by various types of devices at any time, the code must be standardized. Standardization in this field supports efforts to obtain compatibility between various devices or subsystems and opens up opportunities for feature expansion and information exchange between various systems.

5. Increasing resource empowerment is achieving the maximum overall economy by increasing the use of resources such as materials, capital and optimizing human empowerment is an important goal of standardization. In the manufacturing unit, for example, aspects of standardization of materials, components and production methods are utilized to reduce waste and enable the application of production in a better way. For example: civil building construction, mixing of mortar (cement: sand: 
water according to standards) is carried out in the correct ratio, as well as the use of rebar for reinforced concrete so that it reaches the required strength according to the standard recommendations and building guidelines.

6. Better communication and understanding is one of the important functions of the standard to facilitate communication between producers and users/ consumers by specifying the existing subjects and providing confidence that the product ordered meets the requirements stated in the standard. In the national/ international standard various symbols have been defined and thus confusion due to language differences can be eliminated, at least reduced.

7. Maintain security, safety and health Standardization of products to ensure safety and health for the wearer. Examples: seat belts, helmets, rubber gloves; stipulation of safety limits for the use of dyes or preservatives in food, stipulating requirements for electrical insulation on household electrical appliances, design of electric irons must be such that users are free from electric shocks and so on.

8. Environmental conservation is now an important goal of standardization: with a focus on protecting nature from damage that may arise. For example: pollution due to production by industry, use of materials that are difficult to experience weathering (plastics), regulations regarding motor vehicle emissions and so on. Environmental preservation is generally stipulated in certain rules, regulations and regulations or requirements.

9. Ensuring the interests of consumers and society Consumers are now very critical of issues of durability, reliability, energy consumption, fire resistance and so on. Matters like this are required in a standard and information about this can be stated on the label and is the result of an accredited laboratory test.

10. Reducing trade barriers. In this era of globalization, the international community strives to reduce trade barriers by certain countries to limit market access to the entry of other countries' products, for example by setting import duties or setting standards unilaterally. Standards prevent is non-tariff trade barriers through harmonization of requirements (the same standard is at least equal and restricting different standards), thereby enabling healthy competition. Buyers or consumers believe that the level of quality of a product, process or service that has been produced or available is in accordance with recognized standards.

According to the results of the Problem Inventory List analysis conducted by the Ministry of Cooperatives and SMEs in 2010, it is known that many MSMEs that do not have certification or standardization of products tend to be sourced from the inadequate role of supporting institutions. Standardization, socialization about the importance of standardization of MSMEs, bureaucracy in obtaining product standardization, and internal weaknesses of MSMEs related to their limited knowledge, information and technology (Sutrisno, 2012).

Raliby et al., 2013 examined the process of standardization of products in order to increase the competitiveness of IIK. From the results of research using the Participatory Rural Appraisal (PRA) approach or Participatory Understanding of Rural Conditions (PRA), namely approaches and methods that allow people to jointly analyze life problems in order to formulate real plans and policies. The results of the research are with this standardization, it will also have an impact on the selling price of the product. Because so far the selling price of the product is quite low. As a result, although the income is high, but it is not followed by an increase in the welfare of the craftsmen. 


\section{RESEARCH METHODS}

At the beginning of this research, the research method was designed with a qualitative method with an experimental analysis approach to identify and describe the real conditions of the creative industry that occurred in Putri Ranjani Manisan's business. Furthermore, the place of research is of course carried out in the home industry business "Putri Ranjani Manisan" in the Business Group for Increasing Prosperous Family Income (UPPKS) Kasih Ibu Kampung KB, Limau Sundai Binjai Village, Binjai City, North Sumatra, Indonesia which will be analyzed through action research to test its effectiveness. Product standardization to increase sales and revenue. It which will be studied further in this research. In brief, the research stage will be carried out as follows;

\section{Activity Implementation Methods}

Implementation methods offered to partners to overcome problems faced by Creative and Home Industry owners are methods of education, training, socialization and assistance, including:

1. Solutions for packaging design that are less attractive to packaging will be given training in packaging design by the service team,

2. Solutions for products that do not have a halal certificate will be carried out socialization and assistance for product standardization in the production process by taking into account the raw materials used, production space arrangement, work standards and completing the required documents for product certification application until obtaining a halal certificate from LPPOM MUI.

3. Solutions to financial management and business management problems will be provided with education and training in financial accounting and simple management in the form of preparing financial reports,

4. The solution for ineffective marketing will be training on marketing systems using IT through the store

\section{Approach Method to Solve Problems}

Based on the problems that have been stated, in this PPM-BOPTN activity the approach method used is the method of education, training, socializing and mentoring. The approach method offered to solve this problem operationally is as follows:

1. Observing the business conditions of partners to identify problems faced regarding product standardization and certification, packaging used, financial management and marketing systems.

2. Design attractive packaging designs for partner products

3. Provide packaging design education and training so that product packaging becomes neater and more durable.

4. Conduct socialization and assistance for the application of standardization in the production process by taking into account the raw materials used, the arrangement of the production space, work standards and completing the required documents for product certification application to obtain a halal certificate from LPPOM MUI.

5. Providing education and training in financial accounting and business management.

6. Providing education and training in marketing systems using IT through the store application.

\section{Observation}

Before and after standardization will be carried out:

(Through interviews with business owners, and field observations) 
1. Evaluating business plans, including packaging, and marketing

2. Product quality (management, hygiene, and certification)

3. Marketing

4. Income

\section{RESULTS AND DISCUSSION}

Product standardization in the home industry product "Putri Ranjani Manisan" aims to make a role model for a creative business or a good home industry. This is also to provide an example for creative entrepreneurs or other home industries in producing quality products that are competitive in the global market. Where usually the home industry and creative businesses are still not very competitive in the global market. Product presentation and management of home industy products that are still very standard, even spelled out origin. Especially in the culinary field. Many home industry entrepreneurs or creative entrepreneurs do not know and know product standardization.

Especially during this pandemic, people are forced and must choose to live their daily lives that must be more careful and live cleaner than before. In other words, this encourages consumers to prioritize more on hygiene, certification, and standardization in the use of any product, especially food. In an effort to standardize this will have several positive effects on confectionery entrepreneurs in creative businesses or home industries.

\section{The Stage before Identifying And Standardizing The Product}

According to Ibu Putri Ranjani as the owner of the "Putri Ranjani Manisan" business (Interviewed, 28 ${ }^{\text {th }}$ July 2020):

"Yes, I don't have a business plan. Well, I only sell Manisan products that I manage from young papaya. I made it with much sugar and I sold them and my income in one day, I split into two are for necessary to eat tomorrow and made Manisan again. "

"I take young papaya from my garden, then I carve it and shape it in various shapes such as flowers, leaves and so on. Next, I color it using food coloring and I soak the sugar. And the management is usually just the usual traditional ones. And sold it wrapped in plastic and tied with rubber. "

"For marketing, I only sell it in front of my house. I already have someone who is a regular customer around my house. Most of the customers are around this area. "

"So far, my income is around 30,000 to 100,000 per day. But during this pandemic, my income has decreased, and my customers don't usually buy anymore. "

From the interview results above, it can be concluded that the problems faced by the entrepreneur "Putri Ranjani Manisan" will be summarized in the table below: 
Table 1. Problems faced by the owner of "Putri Ranjani Manisan" business during the pandemic

\begin{tabular}{|c|c|c|}
\hline No & Problems & $\begin{array}{c}\text { The problem of Owner of } \\
\text { "Putri Ranjani Manisan" }\end{array}$ \\
\hline 1. & $\begin{array}{l}\text { Limited knowledge on } \\
\text { the product certification } \\
\text { standardization process }\end{array}$ & $\begin{array}{l}\text { Lack of partner knowledge about product standardi- } \\
\text { zation and how to obtain a halal certificate from } \\
\text { LPPOM MUI } \\
\text { - Culinary products cannot be marketed outside the city }\end{array}$ \\
\hline 2. & Packaging Design & $\begin{array}{l}\text { - There is no packaging design / using plastic bags } \\
\text { - Don't use any design tools }\end{array}$ \\
\hline 3. & Financial management & - financial Statement Report \\
\hline 4. & Marketing & $\begin{array}{l}\text { - Cannot be marketed outside the city and modern markets } \\
\text { - Lack of understanding of online marketing alternatives }\end{array}$ \\
\hline
\end{tabular}

Based on Table 1.1, the priority problems faced by partners are: 1) The lack of partner knowledge in the standardization and halal certification process so that it is difficult to compete with other similar products, 2) Simple and unattractive packaging design 3) Financial management is still very simple, 4) Less understanding of marketing alternatives.

\section{Stage of Product Standardization}

\section{Packaging Design}

At this stage, the confectioner's owner learns and discusses packaging design with several researchers and the community service team.

\section{Halal labeling}

Inclusion of written or halal statement on the packaging of the confectionary product to show that the product in question is a halal product. It which is authorized by the Government in the halal certification process, namely Indonesian Ulama Council (MUI).

\section{Participating in Training on Financial Management Arrangement for the creative or home industry}

Training and material on financial management so that it is expected to be able to manage finances and be able to calculate profits and losses from the sales proceeds.

\section{Following Marketing System Training Using Social Media}

At this stage, it is trained to create and manage a store account on social media to market products. With this it is able to manage the online market and sell its products to various cities.

\section{The Stage after Identifying and Standardizing the Product}

According to Ibu Putri Ranjani as the owner of the "Putri Ranjani Manisan" business.(Interviewed, $28^{\text {th }}$ December 2020):

"After attending the training, I came here more and more understand how to manage a good business. Although a small business can be global. As long as I can understand running the business. After participating in the product standardization training, I can also sell it through social media. Via Facebook, it's not only people from around here who buy it but also the village next door and I've also sent Manisan to Medan. He said that after doing MUI labeling, I could sell my products to mini markets, and my sales also increased after I marketed them through social media and there was good packaging". 
Table 1. Solutions obtained by the business owner "Putri Ranjani Manisan" after product standardization.

\begin{tabular}{|c|l|l|}
\hline No & \multicolumn{1}{|c|}{ Problem } & \multicolumn{1}{c|}{ Solution } \\
\hline 1. & $\begin{array}{l}\text { Limited knowledge on the } \\
\text { product certification } \\
\text { standardization process }\end{array}$ & $\bullet$ Obtained a halal certificate from LPPOM MUI \\
\hline 2. & Packaging Design & $\bullet$ There is an attractive packaging design \\
\hline 3. & Financial management & $\bullet$ Have definite financial books. \\
\hline 4. & Marketing & $\begin{array}{l}\text { • Can be marketed outside the city and modern markets. } \\
\text { - Understand online marketing alternatives }\end{array}$ \\
\hline
\end{tabular}

\section{CONCLUSION}

From the research results above, product standardization is very important to support the smooth running of business and customer trust in the products and services offered. The results also show that product standardization is also very helpful for household products to compete with national and global markets. Knowledge of technology and social media is also one of the most important tools to support massive product marketing to various regions, such as out of town and even abroad. Home industry products will also be one of the solutions to improve regional economic welfare and even Indonesia. Especially in a pandemic situation like this. Financial problems and economic stability are still impacted. With the effort to standardize and commercialize products from the creative industry "Putri Ranjani Manisan", it is necessary to pay attention from the local government in providing continuous training on products and marketing management in maintaining the creativity of the village community. In order to increase household income and local economic growth.

\section{ACKNOWLEDGEMENT}

Thanks are conveyed to Directorate General of Higher Education for providing the grant. Furthermore, thanks were also conveyed to Universitas Negeri Medan for his direction and guidance during the process of Community Service activities.

\section{REFERENCES}

Assauri Sofyan. (2004). Manajemen Produksi dan Operasi. Jakarta: Lembaga Fakultas Ekonomi UI.

Fatah MA, Bachtiar Y. (2004). Membuat Aneka Manisan Buah.Jakarta.AgroMedia Pustaka. ISBN 979-3357-97-5

Koswara, Sutrisno. (2009). Teknologi Pengolaham Buah dan Sayuran.Ebookpangan.com Husaini Usman. (2008). Manajemen. Jakarta: Bumi Aksara.

ISO Guide 2. (2004). Standardization and related activities - General vocabulary. Geneva: ISO.

ISO/IEC Directive Part 1. (2004). Procedures for the technical work. Geneva: ISO.

ISO/IEC Directive Part 2. (2004). Rules for the structure and drafting of International Standard. Geneva: ISO.

T. Hani Handoko. (1984). Manajemen .Yogyakarta: BPFE,

Henri Fayol . (1949). General and Industrial Management. New York: Pitman Publishing. Sri Wiludjeng. (2007). Pengantar Manajemen. Yogyakarta: Garaha Ilmu.

Raliby Oesman, Retno Rusdjijati, dan Nugroho Agung Prabowo (2013).Standarisasi Produk Guna Meningkatkan Daya Saing Ikm Mainan Anak Di Kota Magelang, SNTT, ISSN 2339-028X. 
Sandee H, Ibrahim B. (2002). Evaluation of SME Trade and Export Promotion in Indonesia. Jakarta: ADB Technical Assistance SME Development- Kementrian Negara Koperasi dan Usaha Kecil Menengah.

Soetrisno N. (2005). SME Clustering Strategy In Indonesia: An Integrated Development Support. Di dalam: Improving The Competitiveness of SMEs Through Enhancing Productive Capacity. Proceedings of Four Expert Meetings. New York and Geneva: UNCTAD. pp. 131-137.

Untari Pudjiastuti \& Dohana Viskhurin F, (2010), Manfaat Sertifikasi Bagi Industri Di Indonesia, Jurnal Standarisasi Vol. 9.

Mulyono. (2008). Manajemen Administrasi dan Organisasi Pendidikan. Yogyakarta: ArRuzz Media. 